\title{
Foraging behavior of major insect pollinators on Pumpkin, Cucurbita moschata (Duch.ex Lam)
}

\author{
Lalita* and Yogesh Kumar \\ Department of Entomology, CCS Haryana Agricultural University, Hisar- 125004 (Haryana), INDIA \\ *Corresponding author. Email- lalitapanwar17@gmail.com
}

Received: July 19, 2016; Revised received: February 19, 2017; Accepted: August 6, 2017

\begin{abstract}
Foraging activity period of different honey bee species on $C$. moschata (C-1076) flowers at different day hours during August-September (2013) revealed that $A$. dorsata, $A$. mellifera, $A$. cerana and $A$. florea initiated their activity early in the morning at $0530,0615,0625$ and $0630 \mathrm{~h}$, respectively and stopped their activity at 1030, 1020, 1025 and $1030 \mathrm{~h}$ of the day, respectively while on C. moschata (C-1106, A. dorsata, A. mellifera, A. cerana and A. florea initiated their activity early in the morning at 0535, 0615, 0620 and $0625 \mathrm{~h}$, respectively and ceased their activity at $1045,1025,1015$ and $1040 \mathrm{~h}$ of the day, respectively. The mean foraging speed (time spent per flower) in seconds on flowers of pumpkin (C-1106) was maximum of $A$. florea (181.72), followed by $A$. mellifera (7.15), $A$. cerana (6.05) and $A$. dorsata spent least time (5.83) and in pumpkin (C-1076), foraging speed was maximum in case of $A$. florea (178.71), followed by $A$. mellifera (7.63), $A$. cerana (6.24) and $A$. dorsata spent least time (6.06). The mean foraging rate (flowers visited per minute) on flowers of pumpkin (C-1106) was maximum in case of $A$. dorsata (5.13), followed by $A$. cerana (4.30), $A$. mellifera (4.16) and $A$. florea visited least flower (0.32) and in pumpkin (C-1076), foraging rate was maximum in case of $A$. dorsata (4.96), followed by $A$. cerana (4.19), $A$. mellifera (4.02) and $A$. florea visited least flower (0.33). Present study advises the farmers that they should not apply the pesticide when the activity of honey bee is on the peak period because pesticides application at the time of bee activity in the field crop causes mortality of bees.
\end{abstract}

Keywords: Foraging rate, Foraging speed, Honey bee species, Pumpkin

\section{INTRODUCTION}

Foraging behavior is one of the distinctive behaviors of honey bee species. This behavior is the link between the honey bee colony and the ambient environment. Foraging behavior of pollinators collecting floral resources on pumpkin flowers was arbitrarily divided into three successive periods, based on the bees' positions on squash flowers (e.g. pre-arrival at the flowers; landing on the petal of the flowers; and lingering near the stigma/ anther of the flowers).

The floral size and architecture of $C$. moschata i.e large size petals with campanulate shape provide suitable landing platform for bees. Slight scented, bright flowers attract the bees, especially under sunny condition, when the scent is dispersed far by solar radiation. Since the flowers are short lived and open only for few hours, this period is very important for pollination of this crops. The size and complexity of floral display used to advertise their location is one of the several factors influencing the behavior of pollinators (Goulson, 1999). The high male to female ratio achieves the production of sufficient amount of pollen deposits, thus aids in effective pollination. Foraging activity of insect visitors showed mostly negative correlation with temperature and positive correlation with relative humidity on cloudy days and sunny days. Rainy days showed negative correlation to temperature both positive, negative correlation with relative humidity in terms of insect activity. Elevated temperatures may affect the plant pollinator interaction and reduce the overall food production that leads to food crisis. Food production could be increased with the help of reducing the global warming (Pandian et al., 2012).

\section{MATERIALS AND METHODS}

Studies were carried out at the Research farm and Apiculture Laboratory of the Department of Entomology, Chaudhary Charan Singh Haryana Agricultural University, Hisar during June to December, 2013 on two cultivars of pumpkin viz., C-1076 and C-1106. Flowering in pumpkin crop initiated during AugustSeptember, 2013.

Determination of working behavior of the pollinators: Initiation and cessation time of different insect visitor's activity were recorded. Observation on the insects pollinator's body contact with the anther and /or stigma, whether working from the top of the flower (top worker, bees that stand on the anther or receptacle and push their tongue and frontal part of their body toward nectaries and touch the stigma and/ or anther) or side of the flower (side worker, bees that 


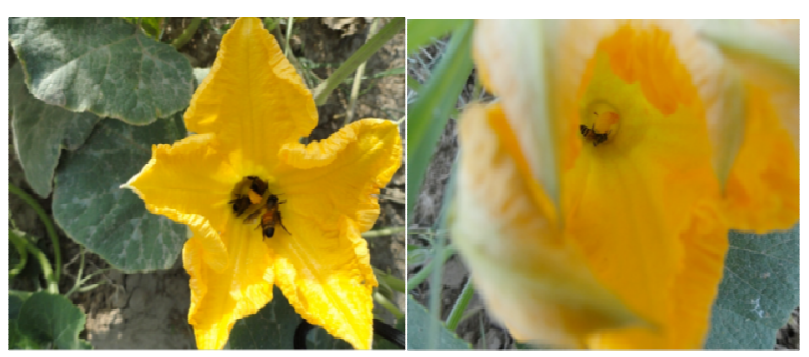

Fig. 1. Apis dorsata foraging Fig. 2. Apis florea foraging on pumpkin flower.

on pumpkin flower.

push their tongue for obtaining nectar between the stamen filament having gap while standing on petal with meso and meta-thorasic legs) were also recorded. Ten individuals of each honey bee species were observed. The observations were recorded throughout the flowering period of the crops.

Determination of foraging speed of the insect pollinators: Foraging speed of honey bees were recorded in terms of time (seconds) spent by them on each flower. A total of ten bees of each species were observed for recording time spent (seconds) by them per flower at peak flowering period of the crop. The time spent to inject the proboscis and suck the nectar or brushing/collecting pollen was considered as the time spent per flower and the same was recorded with the help of a chronometer having an accuracy of 0.01 seconds.
Determination of foraging rate of insect pollinators: Foraging rate of four honey bee species was recorded in terms of the number of flowers visited per minute. A total of ten bee of each species were observed for recording the number of flowers visited per minute at peak activity time of particular species at peak flowering period of the crop. The numbers of flowers visited per minute were recorded including the flying time from one flower to another flower. Ten observations were recorded for each honey bee species.

\section{RESULTS AND DISCUSSION}

Foraging activity: Data pertaining to foraging activity of four honey bee species on C. moschata flowers are presented in Table 1. From the observations noted, it was revealed that all the four honey bee species viz. Apis dorsata, A. mellifera, A. cerana and A. florea, while foraging on pumpkin flowers were found to be top workers. A. dorsata initiated foraging activity on pumpkin flowers little earlier in the morning when compared with A. mellifera, A. cerana and A. florea, and all the four honey bee species ceased their activity till flowers closed (i.e between 1015 to 1045 h). $A$. dorsata, A. mellifera, A. cerana and A. florea, started foraging activity at $0530,0615 \mathrm{~h}, 0620$ and $0620 \mathrm{~h}$ of the day, respectively. Data in table 1 also depict that $A$. dorsata ceased foraging activity at $1030 \mathrm{~h}$ of the day in C-1076 cultivar. However in C-1106 cultivar, A. dor-

Table 1. Initiation and cessation activity time of four honey bee species on C. moschata cultivars, (C-1076 and C-1106) during peak flowering (September, 2013).

\begin{tabular}{|c|c|c|c|c|}
\hline \multirow{3}{*}{ Honey bee species } & \multicolumn{4}{|c|}{ Activity time (hours) } \\
\hline & \multicolumn{2}{|c|}{ Cultivar C-1076 } & \multicolumn{2}{|c|}{ Cultivar C-1106 } \\
\hline & Initiation & Cessation* & Initiation & cessation* \\
\hline Apis dorsata & 0530 & 1030 & 0535 & 1045 \\
\hline Apis mellifera & 0615 & 1020 & 0615 & 1025 \\
\hline Apis cerana & 0620 & 1025 & 0620 & 1015 \\
\hline A. florea & 0620 & 1030 & 0625 & 1040 \\
\hline
\end{tabular}

*The cessation time was due to closing of flowers . The honey bees visit the flowers till their closing.

Table 2. Foraging speed of four honey bee species on C. moschata cultivar (C-1106) flowers at different hours of the day during September, 2013.

\begin{tabular}{|c|c|c|c|c|c|c|}
\hline \multirow{2}{*}{ Honey bee species } & \multicolumn{6}{|c|}{ Time spent per flower (seconds) } \\
\hline & 0530-0630 & 0630-0730 & 0730-0830 & $0830-0930$ & 0930-1030 & Mean \\
\hline Apis dorsata & $6.32(2.72)$ & $6.47(2.74)$ & $6.01(2.50)$ & $5.30(2.43)$ & $5.04(2.68)$ & $5.83(2.61)$ \\
\hline Apis mellifera & $8.28(3.04)$ & $9.50(3.20)$ & $6.17(2.67)$ & $6.01(2.64)$ & $5.79(2.60)$ & $7.15(2.83)$ \\
\hline Apis cerana & $6.44(2.68)$ & $6.57(2.70)$ & $5.52(2.61)$ & $5.44(2.46)$ & $6.27(2.52)$ & $6.05(2.61)$ \\
\hline A. florea & $131.22(11.08)$ & 191.67(13.01) & $202.87(13.61)$ & $216.71(14.28)$ & $167.50(12.50)$ & $181.72(12.90)$ \\
\hline Mean & $38.22(4.88)$ & $53.55(5.41)$ & $55.14(5.35)$ & $58.36(5.45)$ & $46.15(5.06)$ & \\
\hline Factors & \multicolumn{2}{|c|}{$\mathrm{SE}(\mathbf{m})$} & \multicolumn{2}{|c|}{$\mathrm{SE}(\mathrm{d})$} & \multicolumn{2}{|c|}{ C.D. } \\
\hline Bee species & 0.36 & & 0.51 & & 1.01 & \\
\hline Day hours & 0.40 & & 0.57 & & $\mathrm{~N} / \mathrm{S}$ & \\
\hline $\begin{array}{l}\text { Bee species X day } \\
\text { hours }\end{array}$ & 0.81 & & 1.14 & & $\mathrm{~N} / \mathrm{S}$ & \\
\hline
\end{tabular}

Each value represents mean of 10 observations at each sampling time; Figures in parentheses are $\sqrt{(n+1)}$ transformed value. 
Table 3. Foraging speed of four honey bee species on C. moschata cultivar (C-1076) flowers at different hours of the day during September, 2013.

\begin{tabular}{|c|c|c|c|c|c|c|}
\hline \multirow{2}{*}{ Honey bee species } & \multicolumn{6}{|c|}{ Time spent per flower (seconds) } \\
\hline & 0530-0630 & 0630-0730 & 0730-0830 & 0830-0930 & 0930-1030 & Mean \\
\hline Apis dorsata & $6.48(2.72)$ & $6.54(2.74)$ & $5.45(2.48)$ & $5.58(2.51)$ & $6.27(2.86)$ & $6.06(2.63)$ \\
\hline Apis mellifera & $8.67(3.10)$ & $9.57(3.21)$ & $7.14(2.85)$ & $6.97(2.82)$ & $5.79(2.60)$ & $7.63(2.91)$ \\
\hline Apis cerana & $6.74(2.75)$ & $6.75(2.75)$ & $6.30(2.62)$ & $6.35(2.68)$ & $5.04(2.45)$ & $6.24(2.65)$ \\
\hline A. florae & $129.14(10.91)$ & $191.80(12.84)$ & $196.82(13.38)$ & $208.28(13.71)$ & $167.50(12.50)$ & $178.71(12.67)$ \\
\hline Mean & $37.76(4.87)$ & $53.66(5.38)$ & $53.93(5.33)$ & $56.80(5.43)$ & 46.15(5.06) & \\
\hline Factors & \multicolumn{2}{|c|}{ SE(m) } & \multicolumn{2}{|c|}{ SE(d) } & \multicolumn{2}{|c|}{$\begin{array}{r}\text { C.D. } \\
\end{array}$} \\
\hline Bee species & 0.39 & & 0.39 & & $(1.10)$ & \\
\hline Day hours & 0.43 & & 0.43 & & $(\mathrm{~N} / \mathrm{S})$ & \\
\hline $\begin{array}{l}\text { Bee species X day } \\
\text { hours }\end{array}$ & 0.87 & & 0.87 & & $(\mathrm{~N} / \mathrm{S})$ & \\
\hline
\end{tabular}

Each value represents mean of 10 observations at each sampling time; Figures in parentheses are $\sqrt{ }(n+1)$ transformed value.

Table 4. Foraging rate of four honey bee species on C. moschata cultivar (C-1106) flowers at different hours of the day during September, 2013.

\begin{tabular}{|c|c|c|c|c|c|c|}
\hline \multirow{2}{*}{ Honey bee species } & \multicolumn{6}{|c|}{$\begin{array}{l}\text { Flowers visited per minute } \\
\end{array}$} \\
\hline & 0530-0630 h & 0630-0730 & 0730-0830 & 0830-0930 & 0930-1030 & Mean \\
\hline Apis dorsata & $5.64(2.56)$ & $4.38(2.24)$ & $6.47(2.25)$ & $4.67(1.60)$ & $4.51(2.31)$ & $5.13(2.19)$ \\
\hline Apis mellifera & $4.17(2.30)$ & $4.36(2.45)$ & $5.11(1.54)$ & $3.69(2.72)$ & $3.51(2.45)$ & $4.16(2.29)$ \\
\hline Apis cerana & $4.16(2.03)$ & $5.09(1.49)$ & $3.17(2.37)$ & $4.51(2.16)$ & $4.61(2.33)$ & $4.30(2.08)$ \\
\hline A. florea & $0.44(1.20)$ & $0.29(1.12)$ & $0.26(1.11)$ & $0.26(1.11)$ & $0.36(1.16)$ & $0.32(1.14)$ \\
\hline Mean & $3.60(2.06)$ & $3.53(2.04)$ & $3.75(2.08)$ & $3.28(1.99)$ & $3.25(1.99)$ & \\
\hline Factors & \multicolumn{2}{|c|}{ SE(m) } & \multicolumn{2}{|c|}{$\mathrm{SE}(\mathrm{d})$} & \multicolumn{2}{|c|}{ C.D. } \\
\hline Bee species & \multicolumn{2}{|c|}{0.03} & \multicolumn{2}{|c|}{0.05} & \multicolumn{2}{|c|}{$(0.10)$} \\
\hline Day hours & \multicolumn{2}{|c|}{0.04} & \multicolumn{2}{|c|}{0.05} & \multicolumn{2}{|c|}{$(\mathrm{N} / \mathrm{S})$} \\
\hline $\begin{array}{l}\text { Bee species X day } \\
\text { hours }\end{array}$ & \multicolumn{2}{|c|}{0.08} & \multicolumn{2}{|c|}{0.11} & \multicolumn{2}{|c|}{$(0.23)$} \\
\hline
\end{tabular}

Each value represents mean of 10 observations at each sampling time; Figures in parentheses are $\sqrt{ }(x+1)$ transformed value

sata started foraging activity at $0535 \mathrm{~h}$ of the day, $A$. mellifera at $0615 \mathrm{~h}$, A. cerana at $0620 \mathrm{~h}$ and A. florea at $0625 \mathrm{~h}$. A. dorsata ceased foraging activity at $1045 \mathrm{~h}$ of the day followed by A. mellifera, A. cerana and A. florea. In both cultivars, honey bee species stopped foraging activity between 1015 to $1045 \mathrm{~h}$ at Hisar because flowers of pumpkin closed during this period. In general, foraging activity of diurnal insect pollinators starts with sunrise. The flight activity and visitation rates of pollinators are influenced by anthesis and weather parameters like temperature, relative humidity, wind and rainfall (Fageri and Vander Pij1, 1979; Forbes and Cervancia, 1994; Kearns and Inouye, 1993). In Philippine, Deyto and Cervancia (2009) on bitter gourd reported that honey bee (A. mellifera and A. cerana) started foraging activity at $0600 \mathrm{~h}$, while Trigona sp. (Stingless bees) and Halicuts sp. (Solitary bee) exploited the flower at $0630 \mathrm{~h}$ and other flower visitor at around $0700 \mathrm{~h}$. When foraging for pollen or nectar, honey bees were on the top stamens in such a way that their bodies were always in contact with the anthers. They would land directly on stamen or on petals and then walk toward top of the anther. Honey bee collecting nectar spent longer time on flower. Bees collected cucumber pollens heavily from 0800 to 1000 $\mathrm{h}$ and nectar from 1000 to noon (Amaral et al., 1963).
Pernal and Currie (2010) reported a higher foraging rate mean during the afternoon period (36.02 foragers/ min) than during the morn-ing period (17.66 foragers/ min). Yucel and Duman (2005) found that honey bee workers visited onion flowers from 8.15 to $16.30 \mathrm{~h}$ and the peak foraging was between 11.00 to $12.00 \mathrm{~h}$. Foragers have the ability to remember the time of the day at which the higher food resources are available as found with Sysirinchium palmifolium plants (Silva et al., 2013) and such ability may correlate with foraging activity peaks.

Foraging speed four honey bee species on $C$. moschata cultivar (C-1106) flowers during September, 2013: The data on foraging speed by four honey bee species on C. moschata cultivar (C-1106) flowers during September, 2013 are depicted in Table 2. Time spent/flower by four honey bee species differed significantly. The mean foraging speed in case of $A$. dorsata during different hours of the day varied between 5.04 to 6.47 seconds followed by A. mellifera (5.79 to 9.50 seconds), A. cerana (5.44 to 6.57 seconds) and 167.50 to 216.71 seconds in case of $A$. florea. The maximum mean time (181.72 seconds)/flower were spent by $A$. florea followed by A. mellifera (7.15 seconds), A. cerana (6.05 seconds) and A. dorsata (5.83 seconds). Irrespective of different bee species, the 
Table 5. Foraging rate of four honey bee species on C. moschata cultivar (C-1076) flowers at different hours of the day during September, 2013.

\begin{tabular}{lllllll}
\hline \multirow{2}{*}{ Honey bee species } & \multicolumn{2}{l}{ Flowers visited per minute } & & & & \\
\cline { 2 - 7 } & $\mathbf{0 5 3 0 - 0 6 3 0}$ & $\mathbf{0 6 3 0 - 0 7 3 0}$ & $\mathbf{0 7 3 0 - 0 8 3 0}$ & $\mathbf{0 8 3 0 - 0 9 3 0}$ & $\mathbf{0 9 3 0 - 1 0 3 0}$ & Mean \\
\hline Apis dorsata & $5.36(2.49)$ & $4.23(2.27)$ & $6.33(2.69)$ & $4.57(2.35)$ & $4.31(2.27)$ & $4.96(2.42)$ \\
Apis mellifera & $4.03(2.21)$ & $4.26(2.28)$ & $4.91(2.41)$ & $3.55(2.12)$ & $3.37(2.41)$ & $4.02(2.22)$ \\
Apis cerana & $4.48(2.23)$ & $4.94(2.41)$ & $3.03(1.99)$ & $4.37(2.29)$ & $4.57(2.29)$ & $4.19(2.59)$ \\
A. florae & $0.47(1.21)$ & $0.30(1.13)$ & $0.27(1.12)$ & $0.25(1.15)$ & $0.35(1.16)$ & $0.33(1.14)$ \\
Mean & $3.48(2.03)$ & $3.43(2.02)$ & $3.63(2.05)$ & $3.18(1.97)$ & $3.15(1.97)$ & \\
\hline Factors & SE(m) & & SE(d) & & C.D. \\
\hline Bee species & 0.04 & 0.05 & & $(0.11)$ \\
Day hours & 0.04 & 0.06 & & (N/S) \\
Bee species X day hours & 0.09 & & 0.13 & & $(0.26)$ \\
\hline
\end{tabular}

Each value represents mean of 10 observations at each sampling time; Figures in parentheses are $\sqrt{ }(x+1)$ transformed value

mean time spent during different day hours differed at $5 \%$ significant level. The mean time spent irrespective of the honey bee species during 0830 to $0930 \mathrm{~h}$ of the day (58.36 seconds/flower) was higher than the time spent during 0730 to $0830 \mathrm{~h}$ (55.14 seconds/flower), 0630 to $0730 \mathrm{~h}$ (53.55 seconds/flower), 0930 to $1030 \mathrm{~h}$ (46.15 seconds/flower) and 0530 to $0630 \mathrm{~h}(38.22 \mathrm{sec}-$ onds/flower) of the day. These findings are in close proximity with the finding of Collison and Martin (1979) that the average time A. dorsata spent on a flower of cucumber was 11.4 seconds per flower to visit 5.3 flowers per minute. Girish (1981) found that A. cerana and A. dorsata spent 34 and 38 seconds per flower, respectively on Cucurbita pepo L., while Foster and Levin (1967) reported that A. cerana and A. dorsata bees spent about 6.6 and 3.15 seconds per flower on two different strains of muskmelon, respectively.

Foraging speed of four honey bee species on $C$. moschata cultivar (C-1076) flowers during September, 2013: The data on foraging speed, i.e time spent/ flower in seconds by four honey bee species on $C$. moschata cultivar (C-1076) flowers during September, 2013 . differed at 5\% significant level significantly (Table 3). The mean foraging speed (time spent/flower in seconds) during different hours of the day in case of A. dorsata varied from 5.45 to 6.54 seconds followed by A. mellifera (5.79 to 9.57 seconds), A. cerana (5.04 to 6.75 seconds) and 167.50 to 208.28 seconds in case of A. florea. The maximum time (178.71 seconds)/ flower were spent by $A$. florea followed by $A$. mellifera (7.63 seconds), A. cerana (6.24 seconds) and $A$. dorsata (6.06 seconds). Irrespective of different bee species, the mean time spent during different day hours differed significantly at 5\% level. In Brazil, Nicodemo et al. (2009) found that A. mellifera visited pumpkin flowers at $1030 \mathrm{~h}$ for nectar and pollen collection. It spent 34.5 seconds/flower for collecting pollen and for nectar collection it spent 43.9 and 29.3 seconds on female and male flower, respectively, whereas, $T$. spinipes collected only nectar, during a mean time of 60.5 seconds per pumpkin flower.
Foraging rate: The data on flowers visited/ minute by four honey bee species on C. moschata cultivar (C1106) flowers have been presented in Table 4 revealed that foraging rate of four honey bee species differed significantly at $5 \%$ level. Data on foraging rate (number of flowers visited/ minute) of $A$. dorsata varied from 4.38 to 6.47 during different hours of the day. The figure ranged between 3.53 to 5.11 flowers in case of A. mellifera, 3.17 to 5.09 flowers in case of A. cerana and 0.26 to 0.44 in case of A. florea. Among four honey bee species, the mean foraging rate was highest in case of $A$. dorsata (5.13 flowers/minute) followed by A. cerana. (4.30 flowers/minute), A. mellifera (4.16 flowers/minute) and it was lowest in A. florea (0.32 flowers/minute). The mean flowers visited per minute were maximum (3.75 flowers/minute) during 0730$0830 \mathrm{~h}$ followed by (3.60 flowers/minute) during 0530$0630 \mathrm{~h},(3.53$ flowers/minute) during 0630-0730 $\mathrm{h}$ and (3.28 flowers/minute) during 0830-0930 h. It was minimum (3.25 flowers/minute) during 0930-1030 h of the day. Foraging rate of forager is influenced by a complex system of factor like temperature and length of corolla tube (Benedek, 1976). Collison and Martin (1979) reported that except in early morning and late afternoon, the average time a bee spent on cucumber flower decreased throughout the day. The average time, 11.4 seconds per flower visit corresponds to a foraging rate of 5.3 flowers per minute in Michigan.

Foraging rate of four honey bee species on $C$. moschata hybrid (C-1076) flowers: The data on flowers visited per minute by four honey bee species on $C$. moschata cultivar (C-1076) flowers are presented in Table 5. The mean foraging rate (flowers visited/ minute) in case of $A$. dorsata varied from 4.31 to 6.33 during different hours of the day. It was 3.55 to 4.91 flowers in case of $A$. mellifera, 3.03 to 4.94 flowers in case of A. cerana and 0.25 to $0.471 \mathrm{n}$ case of A. florea. Among four honey bee species, the mean foraging rate was highest in A. dorsata (4.96 flowers/minute) followed by A. cerana. (4.19 flowers/minute), A. mellifera (4.02 flowers/minute) and it was lowest in $A$. florea (0.33 flowers/minute). Irrespective of different 
bee species, no significant differences were found in the foraging rate of four honey bee species on pumpkin flowers during different hours of the day. The mean flowers visited/ minute were maximum (3.63 flowers/ minute) during 00730-0830 h followed by (3.48 flowers/minute) during $0530-0630 \mathrm{~h}$ followed by $(3.43$ flowers/minute) during 0630-0730 h and (3.18 flowers/ minute) during 0830-0930 h. It was minimum (3.15 flowers/minute) during $0930-1030 \mathrm{~h}$ of the day.

\section{Conclusion}

We concluded that the mean foraging speed (time spent per flower) in seconds on flowers of pumpkin (C -1106) was maximum in case of A. florea (181.72), followed by A. mellifera (7.15), A. cerana (6.05) and A. dorsata spent least time (5.83) and in pumpkin (C1076), foraging speed was maximum in case of $A$. florea (178.71), followed by A. mellifera (7.63), A. cerana (6.24) and $A$. dorsata spent least time (6.06). The size and complexity of floral display used to advertise their location is one of the several factors influencing the behaviour of pollinators. The high male to female ratio achieves the production of sufficient amount of pollen deposites, thus aids in effective pollination. Pumpkin is a cross pollinated crop if bee doec not play role in the transfer of pollen grain from male to female flower, fruit will not set $(0 \%)$ that's why crucial role of bees as providers of pollination services in developing countries cannot be ignored with farmers having A.mellifera colonies, although this service is mainly feral there. Honeybee pollinators are required for producing up to $30 \%$ of the human food supply directly or indirectly and the farmers rely on managed honeybees throughout the world to provide these services. There are many natural and human made challenges that decline many groups of pollinators. Declines are associated with habitat loss, fragmentation, and deterioration, non target pesticide exposure and invasive species. Human activities concern with the establishment of monocultures, overgrazing, land clearing, irrigation so as to modify their habitat in the area of agriculture affect the population of bee species and their abundance.

\section{REFERENCES}

Amaral, E., Mitidieri, J. and Vencousky, R. (1963). Studies on the activities of Apis mellifera L. while visiting the flowers of Cucumis sativus L. Olericultura, 3: 181-193

Benedek, P. (1976). Effect of environmental factors on the foraging rates of honey bees in red clover fields.
Zeitschrift fur Angewandte Entomologie, 81(1): 14-20

Collison, C. H. and Martin, E. C. (1979). Behaviour of honey bees foraging on male and female flowers of Cucumis sativus. Journal of Apicultural Research, 18: 184-190

Deyto, R. C. and Cervancia, C. R. (2009). Floral biology and pollination of Ampalaya (Momordica charantia L.) Philipp. Agri. Scientist, 92(1): 8-18

Fageri, K. and Vander Pijl, L. (1979). The Principles of Pollination Ecology (3rd edn.). Pergamon Press, Great Britain, $244 \mathrm{pp}$

Forbes, M. F. and Cervancia, C. R. (1994). Foraging behaviour of Apis Cerana F. and Apis mellifera L. (Apidae: Hymenoptera) in Malayjay, Laguna. Phil. J. Sci., 23(1): 21-27

Foster, R. E. and Levin, M. D. (1967). F ${ }_{1}$ hybrid muskmelons II, Bee activity in seed fields. J. Ariz. Acad. Sci., 4:222-225

Free, J. B. (1993). Insect pollination of Crops (2nd edn.). Academic Press, London, U.K., 684 pp

Girish, P.P. (1981). Role of bees in the pollination of summer squash (Cucurbita pepo L.) with special reference of Apis cerana F. (Hymenoptera: Apidae). M.Sc. Thesis, University of Agriculture Sciences, Bangalore, Karnataka, India.

Goulson, D. (1999). Foraging strategies of insect for gathering nectar and pollen, and implications for plant ecology and evolution. Prospect Plant Ecol. Evol. Systemat, 2(2): $185-209$

Kearns, C. W. and Inouye, D. W. (1993). Techniques for Pollination Biologists. University Press of Colorado, Niwot, Colorado, 583 pp

Nicodemo, D., Couto, R. H. N., Malheiros, E.B. and De Jong, D. (2009). Honey bee as effective pollinatings agent of pumpkin. Sci. Agric. (Piracicaba, Braz.), 66(4): 476-480

Pandian, K., Baskaran, S., Sundaravadivelan, C., Anburaj, J. and Kuberan, T. (2012). Insect visitors of pumpkin, Cucurbita maxima Duch in relation to temperature and relative humidity. Journal of Agricultural Technology, 8(2): 501-513.

Pernal, S. F. and Currie, R.W. (2010). The influence of pollen quality on foraging behavior in honeybees (Apis mel -lifera L.). Behavioral Ecology and Sociobiology, 51:53 $-68$

Silva, D. P., Moisan-De-Serres, J., Souza, D. C., HilgertMoreira, S.B., Fernandes, M.Z., Kevan, P.G. and Freitas, B. M. (2013). Ef-ficiency in pollen foraging by honey bees: time, mo-tion, and pollen depletion on flowers of Sysirinchium palmifolium (Asparagales: Iridaceae). Journal of Pol-lination Ecology, 11: 27-32

Yucel, B. and Duman, I. (2005). Effects of foraging activity of honeybees (Apis mellifera L.) on onion (Allium cepa) seed production and quality. Pakistan Journal of Biological Sciences, 8:123-126 